\title{
АНАЛІЗ ЗМІНИ ВМІСТУ ВІТАМІНІВ В КОМБІКОРМАХ ПІД ЧАС ЗБЕРІГАННЯ
}

\author{
I. Дударев, С. Уминський, А. Яковенко, В. Макарчук, С. Житков \\ Одеський державний аграрний університет
}

Сучасними дослідженнями підтверджено, щฺо найвища продуктивність сільськогосподарських тварин, визначена на генетичному рівні, має місие, тоді коли організована фізично обгрунтована і збалансована відгодівля тварин та птиці. В активному тваринництві ия тенденція викликає максимальний інтерес до зоологічної науки. Важливо, щэоб кормова база задовольняла потребу тварин у необхідних висококалорійних препаратах та інших деталях. I для иъвого вони зобов'язані діяти в організмі у відповідній кількості та в правильному співвідношенні. Готові комбікорми, які виготовляються 3 урахуванням досягнень передової біохімії та фізіологї тварин, мають усі шанси забезпечити такий баланс завдяки вмісту вітамінів та інших речовин у комонентах комбікормів. Наявність життєво важливих вітамінів в організмі тварин безпосередньо залежить від иінності та властивостей корму, багато з яких містять лище низькі концентрації вітамінів. Крім того, є моменти, які сприяють руйнуванню вітамінів у кормі: - розклад вітамінів відбувається внаслідок зміни перекісного числа ліпідної фракції; - мінеральні препарати речовин, які вводяться в склад комбікорму разом з вітамінами в аква розчинах, окислюють їх; - спостерігається несумісність вітамінів 3 деякими препаратами які додаються за медичними та біологічними показниками; порушення режимів зберігання та його тривалість обумовлюють зміну загальної кількості вітамінів в порівнянні з початковими показниками погіршуючи $\ddot{x}$.

Ключові слова: вітаміни,комбікорм, аналіз, поліном, зміна.

Вступ. Вітаміни - це функціональні речовини на біологічному рівні, які стимулюють обмінні процеси в організмі і потрібні не лише людині. Вітаміни дуже корисні для розмноження, недоступності до іншої сім'ї захворювань та росту організму. Ретінол вітамін А має велике значення в відгодівлі тварин досить : він необхідний для нормального підняття та нормального розмноження та функціювання оргганізму в цілому.Головна функція ретінолу у тварин та птиці, у тому, що він приймаєв процесі регенерації і захисту шкірного покриву i слизових оболонок, імунній відповіді, освіті зорового пурпура, скелета i м'язових тканин, формуванні плодючості тварин, обміну вуглеводів, білків і жирів. Разом 3 цим ретинолом ініціюється вирощування молодняку. Натуральні, природні корм для тварин не містить чистого вітаміну А: він зустрічається лише в молоці, яєчному жовтку, олії печінки тріски та баранячому жирі, проте провітамін А зустрічається в продуктах рослинного походження - каротиноїдах: $\alpha$-, $\beta$-, $\gamma$-каротині та криптоксантині, з яких ретинол Тварини. Простір, в якому каротин перетворюється на вітамін А, - це стінки 
чутливого кишкового тракту. Важливо зазначити, що тварини різної форми та породи відрізняються своєю здатністю перетворювати каротиноїди на вітамін А. Це слід враховувати, перевіряючи А-вітамінну розчинність меню кормів. Наприклад, вітамін А надходить 3 -каротину:). Дефіцит призводить до порушень росту i кісткоутворення, хворобливих змін шкіри та слизової оболонки, а також до порушення зорових функцій (куряча сліпота). Вітамін Е (токоферол) називають виводковим вітаміном. Він регулює репродуктивну функцію у тварин, iї дефект викликає морфологічні та активні зміни в репродуктивних органах, що іноді призводять до безпліддя. Крім того, вітамін Е містить властивості антиоксиданту, який допомагає засвоювати та підтримувати вітамін А та каротин у тварин. Нагромадження токсичних продуктів жирового обміну, недотримання репродукції та м'язова дистрофія тварин пов'язані з дефектом вітаміну Е. Наявність життєво важливих вітамінів в організмі тварини безпосередньо залежить від цінності та властивостей корму, багато з яких містять лише низькі концентрації вітамінів.

Проблема. Аналіз змін у вітамінному складі комбікормів при зберіганні 3 врахуванням тривалісті зберігання.

Аналіз останніх досліджень та публікацій. Вимоги до якості та простежуваності компонентів кормів стереотипні у всіх можливих частинах світу. Він вимагає найвищої чистоти вітамінів, компонентів корму, які не $\epsilon$ генетично модифікованими та вважаються постійними в ДНК, та компонентів без ризику виникнення нестійкої поведінки. Актуальним є питання про те, щоб, як можна вишче забезпечити стійкість вітамінів, які $\epsilon$ компонентами комбікормів для тварин та птиці та які вітамінні продукти дозволяють чудово змішуватися 3 іншими інгредієнтами та які, згідно з передовою інформацією, вирощуються. Вітаміни вважаються однією з нестійких добавок у виробництві кормів для тварин. Залежно від власних хімічних властивостей окремі молекули вітаміну чутливі до фізичних та хімічних моментів. На силу вітамінів впливають усі можливі моменти, які спрацьовують під час переробки корму та при зберіганні преміксів та кормів. Моменти, що впливають на силу вітамінів, включають температуру, тиск, вологість, тертя та окислювальновідновлювальні реакції. Їх вплив може змінюватись в залежності від різних технологій переробки кормів [2]. Загальні обставини, що впливають на стабільність вітамінів у преміксах та комбікормах, можна розділити на фізичні, фізико-хімічні, хімічні та технологічні. До фізичних та фізико-хімічних факторів належать: тепло, тиск, вологість, тертя між частинками, світло, рH, фізико-хімічні властивості вітамінів, солей та інших сполук макро- i мікроелементів, електростатичні властивості компонентів та наповнювача. Хімічні реакції окислення та відновлення окремих вітамінів внаслідок взаємодії з солями мікроелементів та продуктів окислення жиру, руйнування вітамінів під час фотолізу, взаємодії вітамінів за принципом антагонізму. Склад преміксів, форма приготування вітамінів і солей мікроелементів, властивості наповнювача: вологість, розмір частинок, рівномірність перемішування, властивості виробництва преміксів та кормів для тварин у певній компанії, умови зберігання та термін зберігання - це технологічні фактори визначити 
стійкість вітамінів. Зміна активності вітамінів у виробництві та зберіганні преміксів та кормів для тварин $\epsilon$ складним процесом, зумовленим комбінованою дією вищезазначених груп факторів. [3] Руйнівна дія певних факторів на активність вітамінів залежить від процесів, в яких вживаються вітаміни. При виробництві комбікормів вітаміни піддаються впливу тепла, тиску та вологи під час грануляції, екструзії або розширення, а при виробництві преміксів відбувається взаємодія з високоагресивними інгредієнтами (хлорид холіну, органічні кислоти, солі мікроелементів), які присутні у високій концентрації у преміксах в наявності. [1] Надалі, як у преміксах, так і у комбікормі, на стабільність вітамінів і обумовлюють час зберігання. Для досягнення мінімальної втрати вітамінної продуктивності ці компоненти постачаються в кормову промисловість у стабільному вигляді. Стабілізація вітаміну здійснюється за допомогою двох різних технологій: Хімічна стабілізація.( Для таких вітамінів, як вітамін А (ретинол), вітамін Е (альфатокоферол) та вітамін С (аскорбінова кислота) реактивні гідроксильні групи молекул вітаміну захищені методом етерифікації. Антиоксиданти - ще один захист проти чутливих до кисню вітамінів). Захист шляхом інкапсуляції. (Фізичний дефект між киснем та чутливими вітамінними молекулами розглядається як захист від оксигенації та впливу вологи).

Мета роботи: застосування емпірічної залежності для визначення втрат вітамінів під час зберігання.

Результати досліджень. Експериментальні дослідження зміни вмісту вітамінв Е , А, відбувалися для двох видів комбікормів для ПК1-25 (для курей несучок) та для К55-13 (для відгодівлі свінів). На першій стадії досліджень була поставлена серія дослідів по визначенню зміни вмісту вітамінів при тривалості зберігання 60 діб. і початкової вологості комбікорімів $\mathrm{W}=12,5 \%$. Параметри середовища зберігання змінювалися в сле ᄀдующіх межах: температура повітря $\mathrm{t}=-2, \ldots, 8^{\circ} \mathrm{C}$, відносна вологість $\varphi=80, \ldots, 87 \%$. Зберігання комбікормів проізводілоась із застосуванням консерванту сантохіна з вмістом Ск $=0,07 \%$ i без нього.

Таблица 1. Зміна вмісту вітамінів в процесі зберігання розсипного комбікорму ПК $1-25\left(\mathrm{t}=-2,0 . .8,0^{\circ} \mathrm{C}, \varphi=80 \ldots 87 \%, \mathrm{~W}=12,5 \%\right)$.

\begin{tabular}{|c|c|c|c|c|c|c|c|c|c|c|}
\hline \multirow{4}{*}{ Вітаміни } & \multicolumn{2}{|c|}{$\begin{array}{l}\text { Вихідний зміст } \\
\text { вітамінів г/T }\end{array}$} & \multicolumn{6}{|c|}{ Зміст вітамінів $\mathrm{C}_{i}, \Gamma / \mathrm{T}, \%$} & \multirow{2}{*}{\multicolumn{2}{|c|}{$\begin{array}{l}\text { Дослідницькі } \\
\text { дані }\end{array}$}} \\
\hline & \multirow{3}{*}{$\begin{array}{l}\text { Розра- } \\
\text { хункове }\end{array}$} & \multirow{3}{*}{$\begin{array}{l}\text { Дослід- } \\
\text { ницьке }\end{array}$} & \multicolumn{6}{|c|}{ Час зберігання $\tau_{x, \text { діб }}$} & & \\
\hline & & & 10 & 20 & 30 & 40 & 50 & 60 & $\beta_{i}$ & $\tau_{n i}$ \\
\hline & & & \multicolumn{6}{|c|}{ Зберігання без консерванту } & & \\
\hline $\mathrm{A}$ & 3,64 & 3,56 & 3,09 & 2,67 & 2,35 & 2,03 & 1,78 & 1,53 & 0,0139 & 50 \\
\hline \multirow[t]{2}{*}{$\mathrm{E}$} & 26,75 & 26,62 & 2547 & 2434 & 2333 & 2232 & 2136 & 2044 & 0,0044 & 159 \\
\hline & & & \multicolumn{5}{|c|}{ Зберігання з консервантом } & & & \\
\hline $\mathrm{A}$ & 3,64 & 3,56 & 3,39 & 3,23 & 3,08 & 2,93 & 2,79 & 2,67 & 0,0048 & 144 \\
\hline $\mathrm{E}$ & 26,75 & 26,62 & 25,94 & 25,27 & 24,62 & 2399 & 23,37 & 22,77 & 0,0026 & 264 \\
\hline
\end{tabular}

Зміна вмісту вітамінів в залежності від часу зберігання при зазначених режимах наведено в таблицях 1,2,де також представлені розрахункові величини 
коефіцієнта пропорціональності втрат $\beta_{\mathrm{i}}$ i полупериода втрат $\tau_{\text {ni. }}$ Результати, наведені в таблицях, дозволяють зробити висновок про позитивний вплив антіокиданту на зміну вмісту досліджуваних вітамінів. Так, наприклад, для комбікорму ПК1-25 при тривалості зберігання протягом 40 діб. Зміст вітаміну А при зберіганні без сантохіна становило 57\% від початкового змісту, а при зберіганні з сантоніном - 82,3\%, Для комбікорму К55-13 ці величини відповідно складали 63\% і 83,3\%. Аналогічне вплив надає антіоксидант на вітамін Е. Наведений аналіз підтверджується значеннями коефіцієнтів $\beta_{\mathrm{i}}$ і полупериода втрат $\tau_{\mathrm{ni}}$.

Таблица 2. Зміна вмісту вітамінів в процесі зберігання розсипного комбікорму К $55-13\left(t=-2,0 . .8,0^{\circ} \mathrm{C}, \varphi=80 \ldots 87 \%, \mathrm{~W}=12,5 \%\right)$.

\begin{tabular}{|c|c|c|c|c|c|c|c|c|c|c|}
\hline \multirow{4}{*}{ Вітаміни } & \multicolumn{2}{|c|}{$\begin{array}{l}\text { Вихідний зміст } \\
\text { вітамінів г/T }\end{array}$} & \multicolumn{6}{|c|}{ Зміст вітамінів $\mathrm{C}_{i}$, г/т, \% } & \multirow{2}{*}{\multicolumn{2}{|c|}{$\begin{array}{l}\text { Дослідницькі } \\
\text { дані }\end{array}$}} \\
\hline & \multirow{3}{*}{$\begin{array}{l}\text { Розра- } \\
\text { хункове }\end{array}$} & \multirow{3}{*}{$\begin{array}{l}\text { Дослід- } \\
\text { ницьке }\end{array}$} & Чac 3 & еріган & $\tau_{x,}$ ді & & & & & \\
\hline & & & 10 & 20 & 30 & 40 & 50 & 60 & \multirow[t]{2}{*}{$\bar{\beta} \beta_{i}$} & \multirow[t]{2}{*}{$\tau_{n i}$} \\
\hline & & & \multicolumn{6}{|c|}{ Зберігання без консерванту } & & \\
\hline $\mathrm{A}$ & 2,01 & 1,92 & 1,71 & 1,52 & 1,36 & 1,21 & 1.08 & 0,96 & 0,0116 & 60 \\
\hline $\mathrm{E}$ & 34,84 & 33,76 & 32,48 & 31,26 & 30,0 & 28,94 & 27,85 & 26,20 & 0,0038 & 182 \\
\hline & & & \multicolumn{5}{|c|}{ Зберігання з консервантом } & & & \\
\hline $\mathrm{A}$ & 2,01 & 1,92 & 1,84 & 1,76 & 1,68 & 1,60 & 1,53 & 1,47 & 0,004 & 301 \\
\hline $\mathrm{E}$ & 34,84 & 33,76 & 32,98 & 32,24 & 31,54 & 30,84 & 30,15 & 29,48 & 0,0023 & 577 \\
\hline
\end{tabular}

Для комплексної оцінки і математичного опису результатів зберігання комбікормів була поставлена друга серія дослідів для п'яти незалежних варійованих факторів, які включають $\mathrm{W}$ - вологість; $\tau_{\mathrm{x}^{-}}$час зберігання; tтемпература; Р-однорідністі суміші; $\mathrm{C}_{\mathrm{K}}-$ наявність антиоксиданту. В результаті обробки дослідницьких даних для кожного з вітамінів були отримані емпіричні залежності, відповідні аналітичним виразам для визначення їх втрат в процесі зберігання до 40 діб. 3 цією метою при розрахунках коефіцієнтів інтерполяційних поліномів досвідчені значення змісту вітамінів були представлені в логарифмічній формі:

$\lambda=\ln \mathrm{C}_{\mathrm{i}} / \mathrm{C}_{\text {ні }}(1)$

$\mathrm{C}_{\mathrm{i}}$ та $\mathrm{C}_{\text {ні }}$ - відповідно поточне $\mathrm{i}$ початковий зміст $\mathrm{i}$-того вітаміну комбікорму, г/т.

Емпіричні вирази для визначення втрат вітамінів при зберіганні комбікорму ПК1-25 мають вигляд для вітаміну А:

$\mathrm{m}_{\mathrm{a}}=3,56\left(1-\eta_{\mathrm{a}} \mathrm{e}^{-0,0038 \tau} \mathrm{x}\right)(2)$

Емпіричні вирази для визначення втрат вітамінів при зберіганні комбікорму ПК1-25 мають вигляд для вітаміну Е:

$$
\mathrm{m}_{\mathrm{e}}=26,62\left(1-\eta_{\mathrm{e}} \mathrm{e}^{-0,002 \tau} \mathrm{x}\right)(3)
$$


Емпіричні вирази для визначення втрат вітамінів при зберіганні комбікорму мають вигляд для вітаміну А для К 55-13:

$$
\mathrm{m}_{\mathrm{a}}=1,92\left(1-\eta_{\mathrm{a}} \mathrm{e}^{-0,0043 \tau} \mathrm{x}\right)(4)
$$

Емпіричні вирази для визначення втрат вітамінів при зберіганні комбікорму К 55-13мають вигляд для вітаміну Е:

$$
\mathrm{m}_{\mathrm{e}}=33,76\left(1-\eta_{\mathrm{e}} \mathrm{e}_{\mathrm{x}}^{-0,0022 \tau}\right)(5)
$$

Аналізуючи отримані дані слід зробити висновок, що найбільший вплив на втрати вітамінів при зберіганні комбікорми ПК1-25 надає вологість продукта, потім температура середовища зберігання, зміст консерванту, час зберігання i коефіцієнт однорідності суміші. Аналогічні підсумки були отримані під час аналізу виражень для оцінки впливу вихідних факторів на величину втрат вітамінів під час зберігання комбікорму рецепту К-55-13.

Висновки. За результатами виконаних досліджень під час зберігання рецептів комбікормів ПК1-25 ma К-55-13 до 60 діб 3 використанням консерванту та без нього. Отримано емпірічні дані для визначення втрат вітамінів групи А, E підчас їх зберігання. Встановлено найбільший вплив зовнішніх факторів, що суттево впливають на стійкість вітамінів у складі комбікормів.

\section{ЛІТЕРАТУРА}

1. Головня Е. Сохранность витаминов группы «В» в составе витаминноминеральных комплексов // Комбикорма. - 2001. №5. - С 79-80.

2. Дударев I.I., Ісаєв М.В., Плачинта I.Г. Стійкість зберігання комбікормів // Аграрний вісник Причорномор'я. Збірник наукових праць. Технічні науки.Одеса:2018 Вип.90 - С. 28-42.

2. Сгоров Б. В., Шаповаленко О. І., Макаринська А. В. Технологія виробництва преміксів. Підручник. - Київ.: Центр учбової літератури, 2007. 288 c.

3. Gerald C. Shurson, et al. Effect of metal specific amino acid complexes and inorganic trace minerals on vitamin stability in premixes // Animal Feed Science and Technology.- 2011. - Vol. 163 (2). - P 200 - 206.

\section{АНАЛИЗ ИЗМЕНЕНИЯ СОДЕРЖАНИЯ ВИТАМИНОВ В КОМБИКОРМАХ ВО ВРЕМЯ ХРАНЕНИЯ}

Дударев И., Уминский С., Яковенко А., Макарчук В., Житков С.

Современными исследованиями доказано, что самая высокая продуктивность сельскохозяйственных животных, определенная на генетическом уровне, имеет место, тогда как организована физически обоснована и сбалансированная откорм животных и птицыл. В активном животноводстве эта тенденция вызывает максимальный интерес $к$ зоологической науки. Важно, чтобы кормовая база удовлетворяла потребность животных в необходимых высококалорийных продуктах и других деталях. И для этого они обязаньл действовать в организме 8 соответствуюшем количестве и в правильном соотношении. Готовье комбикорма, которые изготавливаются с учетом достижений передовой биохимии и физиологии животных, имеют все иансы обеспечить такой 
баланс благодаря содержанию витаминов и других веществ в комонентах комбикормов. Наличие жизненно важных витаминов в организме животных напрямую зависит от ценности и свойств корма, многие из которых содержат только низкие концентрациии витаминов. Кроме того, есть моменты, которые способствуют разрушению витаминов в корме: расписание витаминов происходит вследствие изменения перекисного числа липидной фракции; - минеральные препараты веществ, которые вводятся в состав комбикорма вместе с витаминами в аква растворах, окисляют их, наблюдается несовместимость витаминов с некоторыми препаратами которые добавляются по медицинским и биологическим показателям; нарушение режимов хранения и его продолюительность обусловливают изменение общего количества витаминов по сравнению с начальными показателями ухудшая их.

Ключевые слова: витамины, комбикорм, анализ, поленом, изменение.

\section{ANALYSIS OF CHANGE OF VITAMIN CONTENT IN FODDER DURING STORAGE}

Dudarev I., Uminsky S., Yakovenko A., Makarchuk V., Zhitkov S.

Modern research has confirmed that the highest productivity of farm animals, determined at the genetic level, occurs when organized physically sound and balanced fattening of animals and poultry. In active animal husbandry, this trend arouses maximum interest in zoological science. It is important that the feed base meets the needs of animals in the necessary high-calorie drugs and other details. And for this they must act in the body in the right amount and in the right ratio. Finished feeds, which are made taking into account the achievements of advanced biochemistry and physiology of animals, have every chance to ensure such a balance due to the content of vitamins and other substances in the components of feed. The presence of vital vitamins in animals directly depends on the value and properties of feed, many of which contain only low concentrations of vitamins. In addition, there are moments that contribute to the destruction of vitamins in the feed: - the decomposition of vitamins occurs due to changes in the peroxide value of the lipid fraction; - mineral preparations of substances that are introduced into the feed together with vitamins in aqua solutions, oxidize them; - there is an incompatibility of vitamins with some drugs that are added for medical and biological reasons; violation of storage regimes and its duration cause a change in the total amount of vitamins in comparison with the initial indicators, worsening them.

Key words: vitamins, compound feed, analysis, logs, change. 